\author{
dr hab. Beata BIESZK-STOLORZ \\ Wydział Nauk Ekonomicznych i Zarządzania, Uniwersytet Szczeciński \\ e-mail: beatus@wneiz.pl
}

DOI: $10.15290 /$ ose.2017.02.86.08

\title{
PLEĆ JAKO DETERMINANTA WYSTĄPIENIA JEDNEJ Z KONKURUJĄCYCH FORM WYJŚCIA Z BEZROBOCIA
}

\begin{abstract}
Streszczenie
Celem artykułu jest analiza wpływu płci osoby bezrobotnej na prawdopodobieństwo wyrejestrowania z urzędu pracy z powodu podjęcia pracy, odmowy lub pozostałych przyczyn. Powody te stanowią różnego rodzaju zdarzenia konkurujące. W badaniu zastosowano metody analizy trwania, przydatne w przypadku występowania danych cenzurowanych. Do oceny ryzyk konkurujących wykorzystano funkcję skumulowanej częstości $(C I F)$. Zbadaniu różnic we wpływie płci na prawdopodobieństwo wyrejestrowania za sprawą określonej przyczyny posłużył test Graya. W badaniu posłużono się danymi indywidualnych osób zarejestrowanych w Powiatowym Urzędzie Pracy w Szczecinie.
\end{abstract}

Słowa kluczowe: analiza trwania, funkcja skumulowanej częstości, test Graya, bezrobocie, płeć

\section{GENDER AS DETERMINANT OF COMPETING FORMS OF LEAVING UNEMPLOYMENT}

\section{Summary}

The purpose of the paper is to analyse the impact of gender on the probability of an unemployed person deregistering from a Labour Office because of finding income-generating work, refusal to accept a job, or other causes. Different competing events might become reasons for such a turn of events. The study uses survival analysis methods, helpful in the case of censored data. The cumulative incidence function $(C I F)$ is used to assess competing risks. Gray's test was applied to examine differences in the influence of gender on the probability of deregistration due to a specific cause. The study was based on data of individual jobseekers registered at the County Labour Office in Szczecin.

Key words: survival analysis, cumulative incidence function, Gray's test, unemployment, gender

JEL: C41, J64.

\section{Wstęp}

Liczne badania potwierdzają istotne różnice w sytuacji kobiet i mężczyzn na rynku pracy w Polsce [Strukturalne i kulturowe uwarunkowania..., 2009; Bieszk-Stolorz, Markowicz, 
2013; Matuszewska-Janica, Hozer-Koćmiel, 2015]. Trudniejsza sytuacja kobiet w tym obszarze wynika z szeregu barier i przeszkód, z którymi wciąż muszą mierzyć się. Świadczą o tym utrzymujące się od lat czynniki, takie jak: niższy współczynnik aktywności zawodowej, niższy wskaźnik zatrudnienia, wyższy poziom bezrobocia, brak równości w wynagrodzeniach kobiet i mężczyzn, mała obecność kobiet na wyższych stanowiskach i w zarządach firm [Rynek pracy wobec zmian..., 2013].

W ostatnich latach sytuacja kobiet ulega stopniowej zmianie. Proces ten jest związany z przemianami współczesnego rynku pracy. Jednak nadal skomplikowana sytuacja kobiet głównie wiąże się z podwójną rola, jaką pełnią kobiety, czyli aktywne zawodowo matki lub opiekunki [Aktywność zawodowa i edukacyjna..., 2007]. Zmiany zachodzace na rynku pracy mogą wpływać na polepszenie ich sytuacji. Jest to przede wszystkim upowszechnienie elastycznych form zatrudnienia. W procesie zmian duże znaczenie maja również przemiany społeczne, takie jak odchodzenie od dominującego do niedawna tradycyjnego modelu rodziny na rzecz modelu partnerskiego i wzrost wykształcenia kobiet.

Gorszą sytuację kobiet na rynku pracy potwierdzają dane statystyczne. Według danych BAEL, w IV kwartale 2015 roku współczynnik aktywności zawodowej osób w wieku 15 lat i więcej stanowił 56,5\%, przy czym współczynnik ten dla kobiet wynosił 48,6\%, a dla mężczyzn 65,0\%. Wskaźnik zatrudnienia wyniósł 52,6\% i wskaźnik ten dla kobiet stanowił $45,2 \%$, natomiast dla mężczyzn $60,6 \%$. Stopa bezrobocia w omawianym okresie wyniosła 6,9\%: dla kobiet 7,1\%, zaś dla mężczyzn 6,8\%. W IV kwartale 2015 roku wśród biernych zawodowo przeważały kobiety $(61,5 \%)$. Odsetek kobiet wśród ogółu zarejestrowanych w urzędach pracy w końcu 2015 roku obejmował 52,2\%. W okresach pogorszenia sytuacji na rynku pracy niekorzystne zmiany częściej dotyczyły mężczyzn, tj. szybciej rosła liczba bezrobotnych mężczyzn, a tym samym zwiększał się ich udział wśród zarejestrowanych bezrobotnych. Analiza średniego czasu pozostawania bez pracy pokazuje, że kobiety pozostawały w ewidencji urzędów pracy o 1,7 miesiąca dłużej niż mężczyźni (tj. 13,4 miesiąca wobec 11,7 miesiąca) [Sytuacja kobiet i mę̇́çyzzn ..., 2016]. Kobiety chętniej niż mężczyźni korzystały z subsydiowanych form pracy proponowanych przez urzędy, częściej uczestniczyły w programach zwiększających aktywność zawodowa, pomimo że skuteczność tych programów była niższa od oczekiwań. Kobiety coraz częściej decydowały się na podjęcie działalności gospodarczej [Aktywna polityka rynku pracy..., 2010]. Podjęcie pracy było tylko jednym $z$ wielu powodów wyrejestrowania z urzędów pracy. Zarejestrowani bezrobotni korzystali z możliwości przejścia na rentę lub emeryturę i z zasiłków przedemerytalnych oraz podejmowali naukę w systemie dziennym. Jednym z częstszych powodów wyrejestrowań z urzędu pracy było odmówienie, bez uzasadnionej przyczyny, przyjęcia propozycji odpowiedniego zatrudnienia.

Celem artykułu jest analiza wpływu płci osoby bezrobotnej na prawdopodobieństwo wyrejestrowania $z$ urzędu pracy w następstwie podjęcia pracy, odmowy lub pozostałych przyczyn. Te trzy rodzaje powodów stanowią różne rodzaje zdarzeń konkurujących. Ryzyko konkurujące definiuje się jako zdarzenie, którego pojawienie się wyklucza wystąpienie innego zdarzenia lub fundamentalnie zmienia prawdopodobieństwo zajścia tego 
innego zdarzenia [Gooley i in. 1999]. Zakłada się przy tym, że zdarzenia są od siebie niezależne, czyli wystąpienie zdarzenia określonego typu nie ma żadnego wpływu na prawdopodobieństwo wystąpienia jakichkolwiek innych zdarzeń [Crowder, 1994; 1996; 1997]. Badana jednostka jest w tym samym czasie narażona na różne rodzaje ryzyka. Jednak zakłada się, że ewentualne zdarzenie wynika tylko z jednego z tych czynników, które nazywa się ,przyczyną niepowodzenia” [McKeague i in. 1994].

W badaniu zastosowano wybrane metody analizy trwania, uwzględniające obserwacje cenzurowane. Do oceny ryzyka zdarzeń konkurujących wykorzystano funkcję skumulowanej częstości (cumulat iveincidence function, CIF). W badaniu posłużono się danymi indywidualnych osób zarejestrowanych w Powiatowym Urzędzie Pracy w Szczecinie, wygenerowanych z systemu SYRIUSZ.

\section{Dane wykorzystane w badaniu}

W badaniu wykorzystano anonimowe dane indywidualne pozyskane $z$ Powiatowego Urzędu Pracy w Szczecinie. Analizowano dane 22078 osób bezrobotnych zarejestrowanych w 2013 roku i obserwowanych do końca 2014 roku. Zdarzeniem kończącym obserwację każdej jednostki był moment wyrejestrowania z urzędu. Badano czas od momentu zarejestrowania do momentu wyrejestrowania z określonego powodu. Wdrożenie systemu informatycznego SYRIUSZ w urzędach pracy umożliwiło gromadzenie obszernych danych na temat osób bezrobotnych. Obecnie w rejestrach podaje się kilkadziesiąt powodów wyrejestrowania. Są to między innymi powody związane z: podjęciem zatrudnienia, przejściem na rentę lub emeryturę, kontynuacją nauki, wyjazdem za granicę. Przyczyny te pogrupowano i rozpatrywano w trzech grupach zdarzeń konkurujących, takich jak: praca, odmowa i pozostałe powody (rysunek 1.). Część obserwacji nie zakończyła się zdarzeniem, czyli wyrejestrowaniem w analizowanym okresie. Stanowiły one obserwacje cenzurowane prawostronnie. Liczebność wszystkich grup podano w tabeli 1.

\section{Grupy zdarzeń konkurujących}

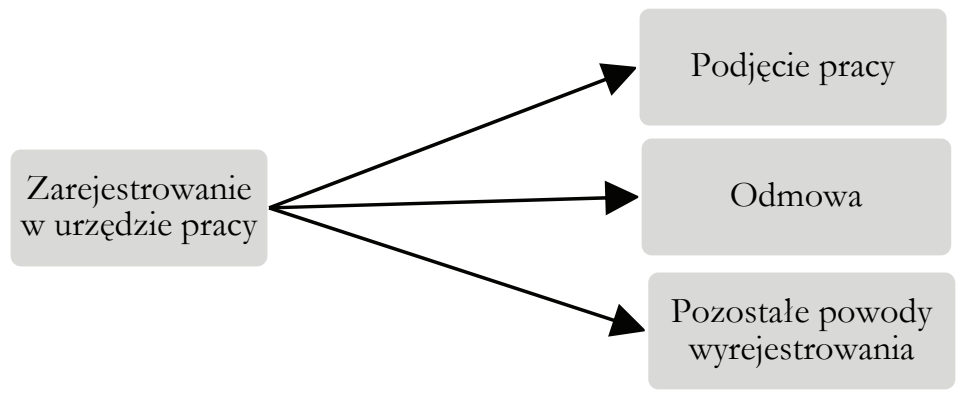

Źródło: opracowanie własne. 
TABELA 1.

Liczebność poszczególnych grup powodów wyrejestrowania

\begin{tabular}{|c|c|c|c|c|c|c|}
\hline \multirow{2}{*}{ Grupy } & \multicolumn{4}{|c|}{ Powód wyrejestrowania } & \multirow{2}{*}{$\begin{array}{c}\text { Obserwacje } \\
\text { cenzurowane }\end{array}$} & \multirow{2}{*}{ Razem } \\
\cline { 2 - 5 } & Praca & Odmowa & Pozostałe & Razem & \\
\hline Kobiety & 4809 & 3264 & 784 & 8857 & 913 & 9770 \\
Mężczyźni & 4824 & 5701 & 840 & 11365 & 943 & 12308 \\
Razem & 9633 & 8965 & 1624 & 20222 & 1856 & 22078 \\
\hline
\end{tabular}

Źródło: opracowanie własne.

TABELA 2.

Charakterystyka głównych powodów wyrejestrowania

\begin{tabular}{|c|c|}
\hline $\begin{array}{l}\text { Powody } \\
\text { główne }\end{array}$ & Powody cząstkowe \\
\hline Praca & $\begin{array}{l}\text { podjęcie pracy lub innego zatrudnienia, podjęcie pracy subsydiowanej przez urząd } \\
\text { (m.in. podjęcie pracy w ramach: robót publicznych, prac interwencyjnych, utwo- } \\
\text { rzonego przez pracodawcę dodatkowego miejsca pracy z tytułu udzielonej po- } \\
\text { życzki, dofinansowania wynagrodzenia za zatrudnienie bezrobotnego, który ukoń- } \\
\text { czył 50. rok życia), działalność gospodarcza (podjęcie pozarolniczej działalności } \\
\text { gospodarczej, przyznanie jednorazowo środków na podjęcie działalności } \\
\text { gospodarczej, rozpoczęcie działalności gospodarczej ze środków PFRON) }\end{array}$ \\
\hline Odmowa & $\begin{array}{l}\text { odmówienie bez uzasadnionej przyczyny przyjęcia propozycji odpowiednie- } \\
\text { go zatrudnienia lub innej pracy zarobkowej, wykonywania prac interwencyj- } \\
\text { nych bądź robót publicznych albo udziału w: szkoleniu, stażu, przygotowaniu } \\
\text { zawodowym w miejscu pracy; niestawienie się w PUP w wyznaczonym ter- } \\
\text { minie i niepowiadomienie w terminie do } 5 \text { dni o uzasadnionej przyczynie tego } \\
\text { niestawiennictwa; nieprzedstawienie zaświadczenia o niezdolności do pracy } \\
\text { wskutek choroby; odmówienie bez uzasadnionej przyczyny udziału w dzia- } \\
\text { łaniach w ramach Programu Aktywizacja i Integracja (PAI) lub z własnej winy } \\
\text { przerwanie udziału w działaniach w ramach PAI; brak gotowości do podję- } \\
\text { cia pracy przez okres co najmniej } 10 \text { dni; z własnej winy przerwanie: szkole- } \\
\text { nia, stażu, realizacji indywidualnego planu działań; wniosek bezrobotnego } \\
\text { o wykreślenie z ewidencji }\end{array}$ \\
\hline Pozostałe & $\begin{array}{l}\text { wyjazd za granice na okres co najmniej } 30 \text { dni, zmiana miejsca zameldowania } \\
\text { lub pobytu zainteresowanego poza obszar działania PUP, niezdolność do } \\
\text { pracy wskutek choroby lub przebywania w zamkniętym ośrodku odwykowym } \\
\text { przez nieprzerwany okres } 90 \text { dni, rozpoczęcie szkolenia organizowanego przez } \\
\text { inny podmiot niz PUP, zgon, powołanie do zasadniczej służby wojskowej, } \\
\text { podjęcie nauki w szkole w systemie dziennym, nabycie prawa do emerytury, } \\
\text { przyznanie prawa do renty, nabycie prawa do świadczenia rehabilitacyjnego, } \\
\text { pobieranie zasiłku stałego, podleganie ubezpieczeniu emerytalno-rentowemu } \\
\text { z tytułu stałej pracy jako domownik w gospodarstwie rolnym, pobieranie świad- } \\
\text { czenia lub dodatku do zasiłku rodzinnego z tytułu samotnego wychowywa- } \\
\text { nia dziecka, pobieranie zasiłku dla opiekuna, przyznanie prawa do pobierania } \\
\text { świadczenia/zasiłku przedemerytalnego }\end{array}$ \\
\hline
\end{tabular}

Źródło: opracowanie własne. 
Na każdy z trzech głównych powodów wyrejestrowania składały się powody cząstkowe (tabela 2.). Podjęcie pracy (praca) obejmowało trzy główne podgrupy, a mianowicie: podjęcie pracy lub innego zatrudnienia, podjęcie pracy subsydiowanej przez urząd, działalność gospodarcza. Odmowa była grupa powodów, w których zarejestrowana osoba bezrobotna nie wykazała się chęcią współpracy z urzędem i została z własnej winy lub na własną prośbę wykreślona z rejestru. Pozostałe powody wyrejestrowania były mniej liczne i, jak wykazały wcześniejsze badania, każda z osób z osobna miała marginalny wpływ na prawdopodobieństwo wyrejestrowania z urzędu. Dlatego postanowiono rozpatrywać je razem.

\section{Metodyka badania}

Metodami analizy trwania, powszechnie stosowanymi w demografii i naukach medycznych do badania czasu trwania życia ludzkiego, można analizować czas trwania zjawisk społeczno-ekonomicznych. Analizie podlega czas trwania jednostki w danym stanie, który jest zmienną losową $T$, aż do momentu wystąpienia określonego zdarzenia kończącego obserwację. Przykładowo może to być: czas działania firmy, czas bezrobocia, czas spłaty kredytu. Zdarzeniami kończącymi obserwację są w tych przypadkach: zakończenie działalności firmy, podjęcie zatrudnienia, spłata kredytu. Metodami analizy trwania można badać: żywotność firm [Markowicz, 2012], aktywność ekonomiczną ludności [Landmesser, 2013], dynamikę ubóstwa w miejskich i wiejskich gospodarstwach domowych [Sączewska-Piotrowska, 2016], ryzyko kredytowe [Matuszyk, 2015; Wycinka, 2015], czas trwania bezrobocia [Bieszk-Stolorz, Markowicz, 2012a; Bieszk-Stolorz, 2013].

Podstawowym pojęciem analizy trwania jest funkcja trwania, nazywana również funkcją przeżycia, zdefiniowana następująco:

$$
S(t)=P(t>T)=1-F(t),
$$

gdzie:

$T$ - czas trwania zjawiska, $F(T)$ - dystrybuanta rozkładu zmiennej losowej $T$.

Funkcja trwania określa prawdopodobieństwo niezajścia zdarzenia co najmniej do czasu $t$. W przypadku demografii i nauk medycznych analizowanym zdarzeniem jest zgon, a estymacji podlega prawdopodobieństwo przeżycia jednostki. W zależności od zdefiniowanego zdarzenia, czasami wygodniej jest analizować dystrybuantę $F(T)$, która wyraża prawdopodobieństwo, że zdarzenie zajdzie najpóźniej do czasu $t$. Dobrym przykładem w tej sytuacji jest badanie czasu trwania bezrobocia. Jeżeli zdarzeniem jest podjęcie pracy przez osobę bezrobotną zarejestrowaną w urzędzie, to estymator funkcji trwania informuje o tym, jakie jest prawdopodobieństwo pozostania w rejestrze, a estymator dystrybuanty pozwala ustalić, jakie jest prawdopodobieństwo podjęcia pracy.

Najczęściej badanie związane z zastosowaniem modeli trwania polega na obserwacji jednostek należących do zdefiniowanej kohorty, czyli zbioru obiektów, wyodrębnionego z populacji z uwagi na zachodzące jednocześnie dla całego zbioru wydarzenie lub proces. Kohorta powinna być wyodrębniona na podstawie istotnych statystycznie cech i jednorodna pod ich względem. Dla każdej z jednostek obserwacji podlega czas trwania 
w danym stanie lub czas trwania procesu. Jeżeli w badaniu jest ustalony okres obserwacji jednostek, to część z nich może nie zaznać zdarzenia przed jego końcem. W takich przypadkach czas trwania dla badanej jednostki jest znany jedynie częściowo. Stanowią one obserwacje cenzurowane prawostronnie. W badaniach za obserwacje takie uznaje się także sytuacje, w których badana jednostka znika z pola widzenia lub występuje zdarzenie kończące obserwację, które wyklucza zajście zdarzenia właściwego [Pepe, 1991], czyli zdarzenie konkurujące. W zastosowaniach medycznych typowym przykładem jest analiza przyczyn śmierci, na przykład w badaniach raka śmierć może nastapić nawrót choroby lub remisja (wywołana skutkami leczenia). Rozróżnienie tych przyczyn ma istotne znaczenie dla całego procesu leczenia. W zastosowaniach inżynierskich ryzyko konkurujące jest związane z wpływem elementów składowych na cały system. Tutaj awaria któregokolwiek ze składników przyczynia się do awarii systemu. Obserwuje się czas, w którym system zawodzi, jak również, który składnik i w jakim stopniu spowodował awarię. W praktyce badawczej obserwacje zakończone zdarzeniem konkurującym można potraktować jako cenzurowane prawostronnie. Jednak ciekawych wyników dostarcza wykorzystanie modeli ryzyk konkurujących [Klein, Moeschberger, 1984; Klein, Bajorunaite, 2004].

Niech Ti $C$ będa zmiennymi losowymi ciagłymi, opisującymi odpowiednio czas do zajścia pewnego zdarzenia i czas do cenzurowania. W przypadku $K$ konkurujących rodzajów ryzyka, obserwacji podlegają pary $(\mathrm{X}, \delta)$, gdzie $X=\min (T, C)$ i $\delta=0,1, \ldots, K$. Jeżeli dana obserwacja jest cenzurowana, to $\delta=0$ oraz $\delta=1, \ldots, k$ dla obserwacji kończących się zdarzeniem (jednym z k konkurujących). W tym kontekście jedno ze zdarzeń $k$ może być uznane za wydarzenie o podstawowym znaczeniu, a wszystkie inne będą rozpatrywane jako zdarzenia konkurujące.

Estymator funkcji skumulowanej częstości występowania po raz pierwszy został zaproponowany przez Kalbfleischa i Prentice'a (2002). Jest to skumulowane prawdopodobieństwa wystąpienia zdarzenia z powodu $k$ przed czasem $t$, przy założeniu, że jednostka jest narażona na wystąpienie któregokolwiek z ryzyk konkurujących k [Bryant, Dignam, 2004]. Funkcja skumulowanej częstości jest zdefiniowana następująco [Klein, Moeschberger, 2003, s. 52]:

$$
C I F_{k}(t)=P(t \leq T, \delta=k)=\int_{0}^{t} s(u) b_{k}(u) d u=\int_{0}^{t} s(u) d H_{k} \text { dla } k=1,2,3, \ldots, K,
$$

gdzie:

$H_{k}(t)$ - funkcja hazardu skumulowanego dla określonego $k$, $S(t)$ - funkcja przeżycia.

Niech $t_{1}<t_{2}<\ldots<t_{i}<\ldots<t_{n}$ będa momentami zachodzenia zdarzeń. Skumulowana funkcja hazardu $H_{k}(t)$ dla przyczyny $k$ może być określona przez estymator Nelsona-Aalena:

$$
\hat{H}_{k}(t)=\sum_{j: t_{j \leq t}} \frac{d_{k j}}{n_{j}},
$$

gdzie:

$d_{k j}-$ liczba zdarzeń z powodu zaistnienia przyczyny $k$, $n_{j}-$ liczba osób zagrożonych w czasie $t_{j}$. 
Jeżeli nie jest znany rozkład czasu trwania analizowanego zjawiska, to do estymacji funkcji trwania najczęściej stosuje się estymator Kaplana-Meiera [Kaplan, Meier, 1958]:

$$
\hat{S}(t)=\prod_{j: t j \leq t}\left(1-\frac{d_{j}}{n_{j}}\right),
$$

gdzie:

$d_{j}$ - liczba zdarzeń w momencie $t_{j}$,

$n_{j}-$ liczba jednostek zagrożonych do momentu $t_{j}$.

Po połączeniu estymatorów: (3) i (4) powstaje estymator funkcji skumulowanej częstości występowania z powodu zaistnienia przyczyny k [Marubini, Valsecchi, 1995]:

$$
C \hat{I F}_{k}(t)=\sum_{j: t_{j} \leq t} \hat{S}\left(t_{j-1}\right) \frac{d_{k j}}{n_{j}} .
$$

Funkcja skumulowanej częstości pozwala wyznaczyć wzorce zajścia zdarzenia z powodu k oraz ocenić, w jakim stopniu każdy powód przyczynia się do całkowitej porażki. Ponieważ $\sum_{k=1}^{K} d_{k j}=d_{j}$, to prawdziwa jest zależność:

$$
\sum_{k=1}^{K} C \hat{I} F_{k}(t)=1-\hat{S}(t)
$$

Jeżeli nie ma zdarzeń konkurujących, to zachodzi równość:

$$
\hat{C I F}(t)=1-\hat{S}(t) \text {. }
$$

Innym sposobem oceny ryzyk konkurujących w badaniu jest zastosowanie wielomianowego modelu logitowego. W analizie trwania modele logitowe traktuje się jako modele hazardu z czasem dyskretnym. Parametry tych modeli pozwalają ustalić względną szansę zajścia zdarzeń konkurujących [Landmesser, 2008; Bieszk-Stolorz, Markowicz, 2012b].

W przypadku zdarzeń konkurujących równość funkcji skumulowanych częstości dla $n$ podgrup weryfikuje test Graya (1988). Test ten porównuje średnie ważone hazardów skumulowanej funkcji częstości. Hipoteza zerowa zakłada brak różnic między funkcjami skumulowanych częstości wyznaczonych dla podgrup. Statystyka testowa ma rozkład chi-kwadrat o $n-1$ stopniach swobody. Jeżeli nie występują zdarzenia konkurujące, test Graya sprowadza się do zwykłego testu log-rank.

\section{Analiza wpływu płci na przyczyny wyrejestrowania z urzędu pracy}

Przeprowadzona analiza składała się z dwóch etapów. Pierwszy z nich dotyczył określenia estymatorów skumulowanej częstości występowania $\left(C I F_{k}\right)$ w stosunku do zdarzenia polegającego na wyrejestrowaniu z urzędu pracy z dowolnego powodu $(k=1)$ dla kobiet i mężczyzn. W tej sytuacji nie wystąiły zdarzenia konkurujące i estymatory skumulowanej częstości były równe dopełnieniu do jedności estymatorów KaplanaMeiera $(1-\mathrm{KM})$ wyznaczonych dla obu grup płci. Danymi cenzurowanymi byly obserwacje, które nie zakończyły się przed końcem 2014 roku. Analizując wykresy obu 
estymatorów (rysunek 2.), widać, że prawdopodobieństwo wyrejestrowania bezrobotnych mężczyzn z dowolnego powodu jest nieco większe niż wobec kobiet. Istotność różnic między krzywymi została potwierdzona testem Graya $\left(\chi^{2}=77,644 ; p=0,000\right)$. Prawdopodobieństwo pozostania w rejestrze urzędu, po 12 miesiącach od momentu zarejestrowania, było równe $0,16 \mathrm{w}$ odniesieniu do mężczyzn i $0,19 \mathrm{w}$ odniesieniu do kobiet. Jest to jednocześnie prawdopodobieństwo przejścia w stan długotrwałego bezrobocia. Do bardziej szczegółowych wniosków na temat przyczyn wyrejestrowania prowadzi analiza ryzyk konkurujących, uwzględniająca różne rodzaje powodów wyrejestrowania (zdarzeń konkurujących).

RYSUNEK 2.

\section{Estymatory skumulowanej funkcji częstości wyrejestrowań z dowolnego powodu dla kobiet i mężczyzn}

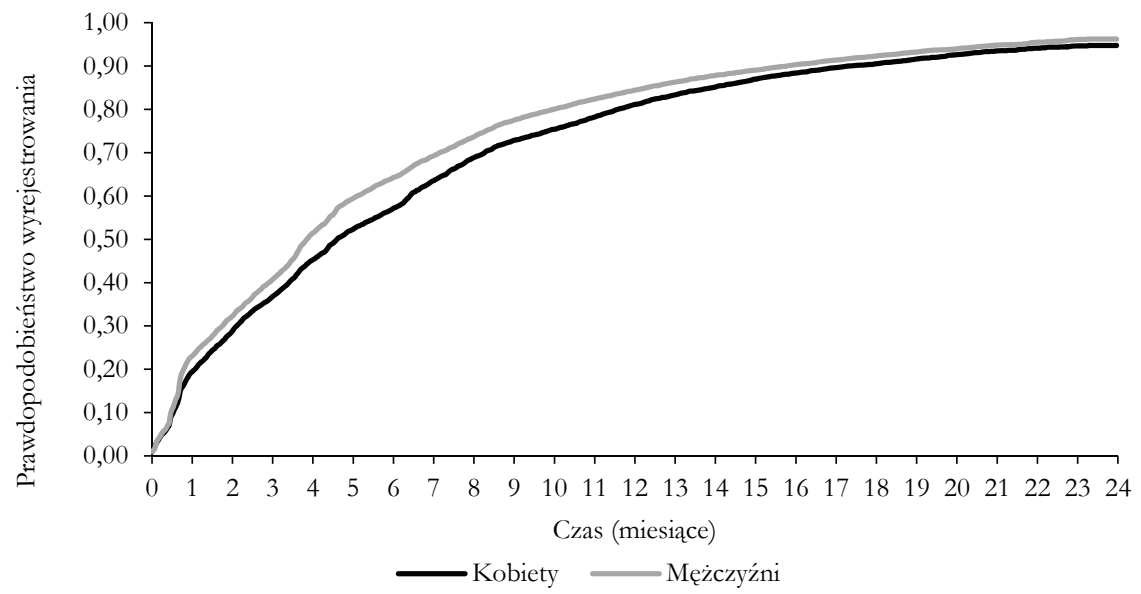

Źródło: opracowanie własne.

TABELA 3.

Wynik testu Graya dla grup bezrobotnych według płci

\begin{tabular}{|c|c|c|}
\hline Przyczyna wyrejestrowania & $\begin{array}{c}\text { Test Graya } \\
\text { (Chi-kwadrat) }\end{array}$ & $\boldsymbol{p}$ \\
\hline Dowolny powód & 77,644 & 0,000 \\
Praca & 190,786 & 0,000 \\
Odmowa & 413,120 & 0,000 \\
Pozostałe & 10,932 & 0,001 \\
\hline
\end{tabular}

Źródło: opracowanie własne.

$\mathrm{Na}$ drugim etapie analizy przyjęto trzy rodzaje zdarzeń kończących obserwację, a mianowicie: podjęcie pracy, odmowa i pozostałe, będące zdarzeniami konkurującymi. Danymi cenzurowanymi, podobnie jak poprzednio, były obserwacje, które nie zakończyły 
się przed końcem 2014 roku. Pozwoliło to na ocenę prawdopodobieństwa głównych powodów wyrejestrowań dla bezrobotnych kobiet i mężczyzn.

Podjęcie pracy było najczęstszym powodem wyrejestrowania dla kobiet w całym okresie trwania w bezrobociu (rysunek 3.). Na drugim miejscu była odmowa. W przypadku mężczyzn najbardziej prawdopodobnym powodem wyrejestrowania była odmowa (począwszy od 4 miesiąca od zarejestrowania), a następnie podjęcie pracy (rysunek 4.). Pozostałe przyczyny były na trzecim miejscu zarówno dla kobiet, jak i mężczyzn oraz miały znaczenie marginalne.

RYSUNEK 3.

\section{Estymatory skumulowanej funkcji częstości $\left(C I F_{k}\right)$ dla różnych powodów wyrejestrowania kobiet}

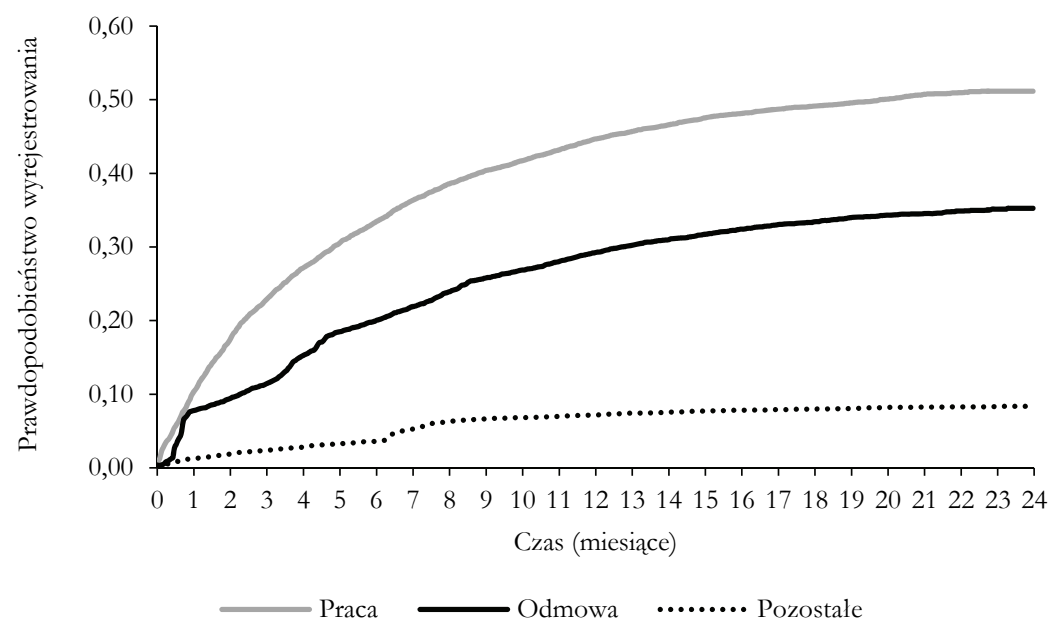

Źródło: opracowanie własne.

Test Graya wskazał na różnice w przebiegu krzywych skumulowanej częstości występowania dla grup wyodrębnionych ze względu na płeć (tabela 3.). Prawdopodobieństwo wyrejestrowania kobiet po 24 miesiącach od zarejestrowania z powodu: podjęcia pracy było równe 0,51 (mężczyźni 0,41), odmowy 0,35 (mężczyźni 0,49), pozostałych przyczyn 0,084 (mężczyźni 0,071). 
RYSUNEK 4. Estymatory skumulowanej funkcji częstości $\left(C I F_{k}\right)$ dla różnych powodów wyrejestrowania mężczyzn

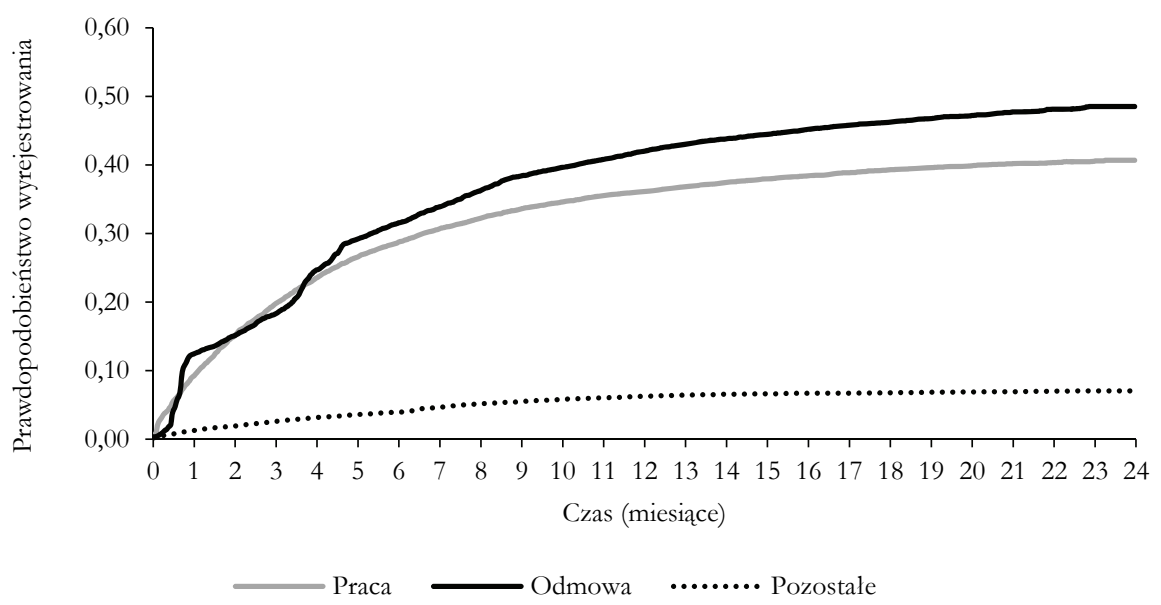

Źródło: opracowanie własne.

Analizując przebieg krzywych, na uwage zasługuje fakt regularnej krzywizny estymatorów powodu praca. Estymatory prawdopodobieństwa odmowy i pozostałych powodów nie posiadały takiej własności. W ich przebiegu można zauważyć krótkotrwałe skoki wartości. Dla grupy pozostałe, zarówno w przypadku kobiet, jak i mężczyzn, niewielki skok wartości nastąpił w siódmym miesiącu od zarejestrowania. Szczegółowa analiza danych potwierdziła, że był on wywołany zwiększoną liczbą wyrejestrowań w tym okresie $z$ racji przyznania zarejestrowanej osobie bezrobotnej prawa do pobierania świadczenia/zasiłku przedemerytalnego. Natomiast dla zdarzenia odmowa znaczący skok w pierwszym miesiącu był związany ze zwiększoną liczbą wyrejestrowań z uwagi na niestawiennictwo osoby bezrobotnej w PUP w wyznaczonym terminie. Te szczegółowe przyczyny wyrejestrowania dotyczyły w równej mierze kobiet, jak i mężczyzn.

\section{Podsumowanie}

Pomoc osobom bezrobotnym w znalezieniu pracy jest jednym z głównych celów urzędów pracy. Wstępna analiza danych indywidualnych pozyskanych z Powiatowego Urzędu Pracy w Szczecinie dowiodła, że podjęcie pracy było najczęstsza przyczyną wyrejestrowania z urzędu dla bezrobotnych ogółem. Badanie przeprowadzone z wykorzystaniem skumulowanej funkcji częstości umożliwiło dokładne zbadanie szans na wyrejestrowanie $z$ urzędu z określonych przyczyn w grupach wyodrębnionych ze względu na płeć, a także ich porównanie. Analiza wykazała różnice w przebiegu krzy- 
wych powodów wyrejestrowań $\left(C I F_{k}\right)$. Praca była najbardziej prawdopodobnym powodem wyrejestrowania w przypadku kobiet, a w grupie mężczyzn odmowa. Otrzymane wyniki sugerują że chęć podjęcia zatrudnienia nie była jedyną przyczyną zarejestrowana się w urzędzie. Pozostałe powody miały znaczenie marginalne.

Aby dokonać bilansu wyników, zsumowano estymatory skumulowanej funkcji częstości w sposób przedstawiony na rysunkach: 5. i 6. Gdyby wszystkie obserwowane osoby zostały wyrejestrowane do końca 2014 roku, to suma estymatorów $C I F_{k}$ dla wszystkich rodzajów ryzyka w 24. miesiącu byłaby równa 1. Jednak w badaniu wystąpiły obserwacje cenzurowane, co spowodowało, że suma ta była mniejsza od 1. Niezerowa różnica, która powstała, pozwala określić prawdopodobieństwo pozostania w rejestrze bezrobotnych po 24 miesiacach od momentu zarejestrowania. W przypadku kobiet było ono równe 0,05, a mężczyzn 0,04.

RYSUNEK 5.

\section{Zsumowane estymatory skumulowanej funkcji częstości $\left(C I F_{k}\right)$ dla kobiet}

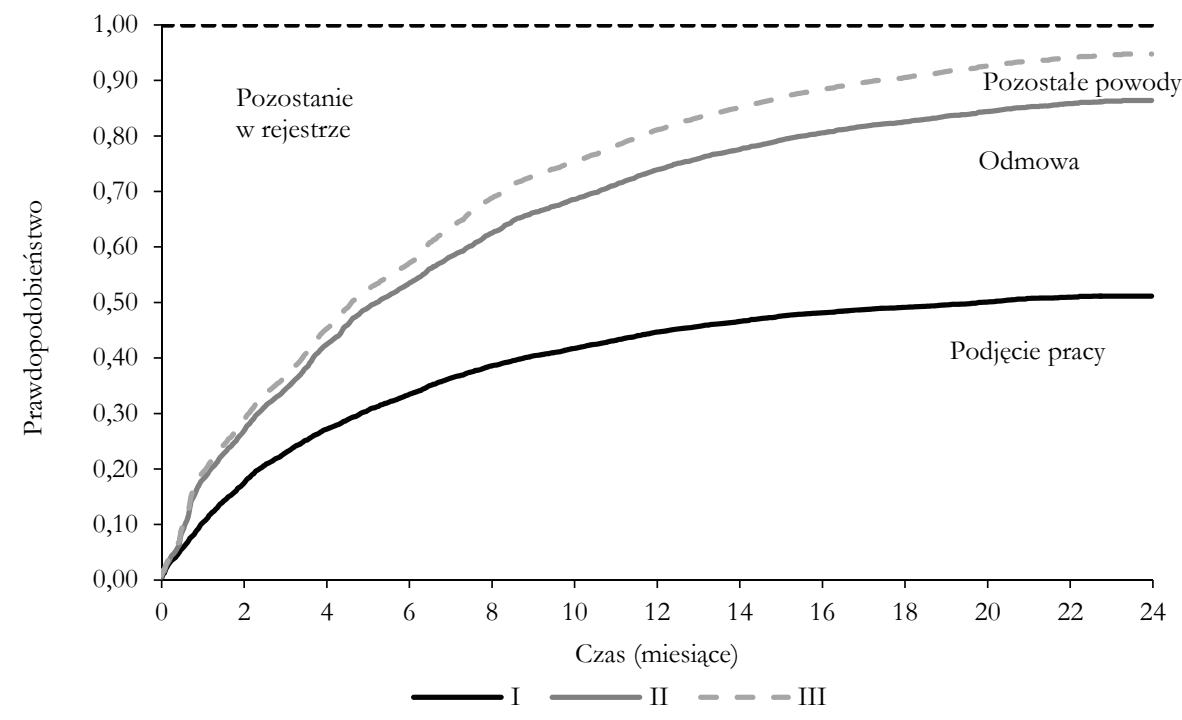

* I - praca, II - praca + odmowa, III - praca + odmowa + pozostałe

Źródło: opracowanie własne.

Odległości ${ }^{1}$ między krzywymi były równe prawdopodobieństwu wyrejestrowania z określonego powodu. Odległość między krzywą III a prostą o wartości 1 była równa prawdopodobieństwu pozostania w rejestrze. Można zauważyć, że zmniejszało się ono w czasie. Jak wcześniej wspomniano, po 12 miesiącach od zarejestrowania w przypadku kobiet było równe 0,19 , a mężczyzn 0,16. Świadczy to o tym, że kobiety cechowało większe prawdopodobieństwo przejścia w stan długotrwałego bezrobocia.

\footnotetext{
${ }^{1}$ Odległość między krzywymi mierzono według metryki $\mathrm{d}\left(\left(\mathrm{x}_{1}, \mathrm{y}_{1}\right),\left(\mathrm{x}_{2}, \mathrm{y}_{2}\right)\right)=\left|\mathrm{y}_{2}-\mathrm{y}_{1}\right|$.
} 
RYSUNEK 6.

\section{Zsumowane estymatory skumulowanej funkcji częstości $\left(C I F_{k}\right)$} dla mężczyzn

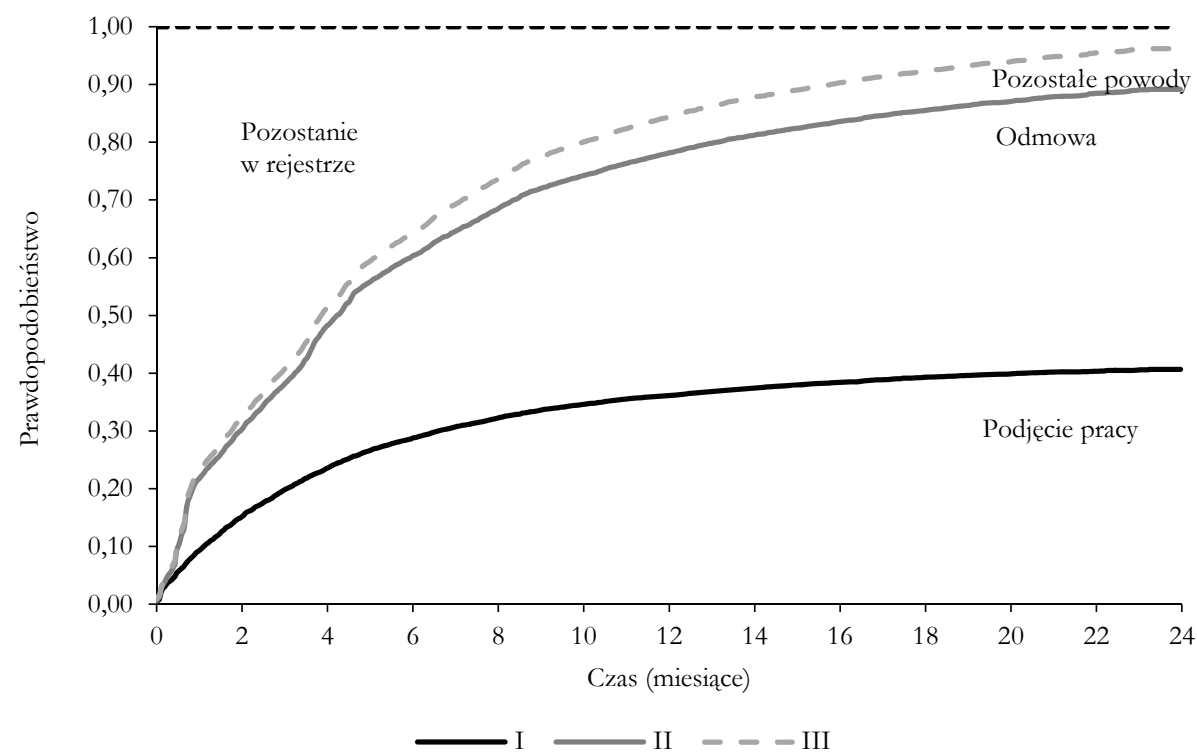

* I - praca, II - praca + odmowa, III - praca + odmowa + pozostałe

Źródło: opracowanie własne.

$\mathrm{Z}$ przedstawionego badania wynika również ważna uwaga metodyczna. Jeżeli występują różne rodzaje zdarzeń kończących obserwację, to warto wyodrębnić zdarzenia konkurujące i oszacować ryzyko ich wystąpienia. Modele skumulowanej częstości pozwalają wyznaczyć prawdopodobieństwo podjęcia pracy oraz porównać je z innymi przyczynami wyrejestrowania.

\section{Literatura}

Aktywna polityka rynku pracy w Polsce w kontekście europejskim, 2010, Z. Wiśniewski, K. Zawadzki (red.), Wojewódzki Urząd Pracy, Uniwersytet Mikołaja Kopernika, Toruń.

Aktywnośc zawodowa i edukacyjna a obowiazki rodzinne w Polsce w swietle badan empirycznych, 2007, I. E. Kotowska, U. Sztanderska, I. Wóycicka (red.),Wydawnictwo Naukowe SCHOLAR.

Bieszk-Stolorz B., 2013, Analiza bistorii zdarzeñ w badaniu bezrobocia, Volumina.pl Daniel Krzanowski, Szczecin.

Bieszk-Stolorz B., Markowicz I., 2012a, Modele regresji Coxa w analizie bęrobocia, Wydawnictwo CeDeWu, Warszawa. 
Bieszk-Stolorz B., Markowicz I., 2012b, Wykorzystanie wielomianowego modelu logitowego do oceny szansy podjecia pracy przez bezrobotnych, „Prace Naukowe Uniwersytetu Ekonomicznego we Wrocławiu", nr 242.

Bieszk-Stolorz B., Markowicz I., 2013, Pteć jako determinanta szansy podjecia zatrudnienia i ryzylea rezygnacji zpośrednictwa urzedu pracy, „Optimum. Studia Ekonomiczne”, nr 6 (66).

Bryant J., Dignam J. J., 2004, Semiparametric Models for Cumulative Incidence Functions, "Biometrics", vol. 60, no. 1.

Crowder M., 1994, Identifiability Crises in Competing Risks, "International Statistical Review", vol. 62 , no. 3 .

Crowder M., 1996, On Assessing Independence of Competing Risks when Failure Times are Discrete, "Lifetime Data Analysis", vol. 2, no. 2.

Crowder M., 1997, A Test for Independence of Competing Risks with Discrete Failure Times, "Lifetime Data Analysis", vol. 3, no. 3.

Gooley T. A., Leisenring W., Crowley J., Storer B. E., 1999, Estimation of Failure Probabilities in the Presence of Competing Risks: New Representations of Old Estimators, "Statistics in Medicine", vol. 18, no. 6.

Gray R. J., 1988, A Class of K-Sample Tests for Comparing the Cumulative Incidence of a Competing Risk, "The Annals of Statistics", vol. 16, no. 3.

Kalbfleisch J. D, Prentice R. L., 2002, The Statistical Analysis of Failure Time Data, Second Edition, John Wiley \& Sons, Inc., Hoboken, New Jersey.

Kaplan E. L., Meier P., 1958, Nonparametric Estimation from Incomplete Observations, "Journal of American Statistical Association", vol. 53.

Klein J. P., Bajorunaite R., 2004, Inference for Competing Risks, [in:] Handbook of Statistics: Advances in Survival Analysis, N. Balakrishnan, C.R. Rao (ed.), vol. 23, Elsevier, Amsterdam.

Klein J. P., Moeschberger M. L., 2003, Survival Analysis: Techniques for Censored and Truncated Data. Second Edition, Springer-Verlag, New York.

Klein J. P., Moeschberger M. L., 1984, Asymptotic Bias of the Product Limit Estimator under Dependent Competing Risks, "Indian Journal of Productivity, Reliability and Quality Control", vol. 9.

Landmesser J. M., 2008, Aktywność ekonomiczna ludności: klasyfikacja osób za pomocq wielomianowych modeli logitowych orazjej zwiazek z. modelami hazardu dla czasów trwania, „Prace Naukowe Uniwersytetu Ekonomicznego we Wrocławiu”, nr 7.

Landmesser J., 2013, Wykorzystanie metod analizy czasu trwania do badania aktywności ekonomicznej ludności w Polsce, Wydawnictwo SGGW, Warszawa.

Markowicz I., 2012, Statystyczna analiza żywotności firm, Wydawnictwo Naukowe Uniwersytetu Szczecińskiego, Szczecin.

Marubini E., Valsecchi M., 1995, Analysing Survival Data from Clinical Trials and Observational Studies, JohnWiley \& Sons, New York.

Matuszewska-Janica A., Hozer-Koćmiel M., 2015, Struktura zatrudnienia oraz wynagrodzenia kobiet $i$ meżçyzn a przedmiotowa struktura gospodarcza w państwach UE, „Prace Naukowe Uniwersytetu Ekonomicznego we Wrocławiu”, nr 385.

Matuszyk A., 2015, Zastosowanie analizy przetrwania w ocenie ryzyka kredytowego klientów indywidualnych, Wydawnictwo CeDeWu, Warszawa. 
McKeague E., Aly E. A. A., Kochar S., 1994, Some Tests for Comparing Cumulative Incidence Functions and Cause-Specific Hazard Rates, "Journal of the American Statistical Association", vol. 89, no. 427.

Pepe M. S., 1991, Inference for Events With Dependent Risks in Multiple Endpoint Studies, "Journal of the American Statistical Association", vol. 86, no. 415.

Rynek pracy wobec zmian demograficznych, 2013, M. Kiełkowska (red.), Instytut Obywatelski, Warszawa.

Sączewska-Piotrowska A., 2016, Dynamika ubóstwa w miejskich i wiejskich gospodarstwach domowych, „Wiadomości Statystyczne”, nr 7.

Strukturalne i kulturowe uwarunkowania aktywności zawodowej kobiet w Polsce, 2009, I. E. Kotowska (red.), Wydawnictwo Naukowe SCHOLAR, Warszawa.

Sytuacja kobiet i męrcayzn na rynku pracy w 2015 roku, 2016, http:/ / www.mpips.gov.pl/ analizy-i-raporty/raporty-sprawozdania/rynek-pracy/ (data wejścia: 01.10.2016).

Wycinka E., 2015, Modelowanie czasu do zaprzestania spłat rat kredytu lub woześniejszej splaty keredytu jako zdarzen konkurujacych, „Problemy Zarządzania”, vol. 13, nr 3 (55), t. 2. 